\title{
N. F. S. Grundtvigs trinitariske folkekirketeologi i nordisk kontekst
}

\author{
Af Hans Raun Iversen
}

Teologi i prægnant forstand deltager i kristen praksis og i sidste instans i den treenige Guds egen kommunikation. Det gælder også for ekklesiologien, der udfolder kirkens teologiske selvforståelse. Derfor må også de nordiske folkekirkers ekklesiologier vurderes ud fra deres forankring i og udfoldelse af triniteten, som ofte er svag. N.F.S. Grundtvigs ekklesiologi kan tolkes som primært kristologisk eller helligåndsteologisk. Det er imidlertid en fejllæsning, for Grundtvigs unikt stærke skabelsesteologi er også en integreret del af hans ekklesiologi. Den første og den anden skabelse er for Grundtvig i lige grad udtryk for Guds handling og må - trinitarisk - tolkes i lyset af hinanden. Akkurat til at fastholde den trinitariske balance i kirkeforståelsen er Grundtvig den bedste læremester, vi har, i de nordiske kirker.

\section{Teologi som deltagelse i trinitarisk kommunikation}

Teologi kan opfattes og praktiseres som en rent intellektuel aktivitet med analyse og eftertanke i forhold til en bestemt kristen tekst eller forståelsesmæssig udfordring. Men teologi i almindelighed og praktisk teologi i særdeleshed kan også opfattes som andet og mere end det især på to måder.

For det første er der en elementært rigtig pointe $\mathrm{i}$ det, når Luther fremhæver, at sand teologi er praktisk, mens den blot spekulative teologi ofte er mere til skade end gavn. En kristen teologi, der drives uden sans for, at kristendommen er et praktisk anliggende, der udfoldes på linje med andre menneskelige aktiviteter, tager ikke sin egen genstand alvorligt. Teologiens primære opgave er at være et refleksivt bidrag til kristen praksis. Enhver praksis forudsætter en form for teori. Teologien fremdrager den teori, der allerede er til stede i kristne praksisformer for at undersøge, hvad den eksisterende teori bidrager med i den givne praksissammenhæng, og for at overveje alternative teoretisk-teologiske muligheder for denne praksis.

Det andet 'mere' i teologien skyldes, at den kristne praksis er af en særlig art. I sidste instans er kristen tro og praksis, teologisk set, igangsat af og deltager i den trinitariske Guds eget kommunikative liv. Det er lettest at illustrere ud fra kirkens liturgi, som traditionen ikke blot anser for at være kirkens praktiserede trosbekendelse - jf. formlen lex orandi lex credendi - men også for at være den primære teologi, theologia prima (Prenter 1987 og Lathrop 1994, 38). I liturgien taler 
Gud til mennesker og mennesker til Gud. Derfor må teologien gennem aktiv lytning og indlevelse i liturgien forsøge at forstå, hvad der er på spil i denne udveksling mellem Gud og mennesker. Gud er imidlertid ikke blot en fjern instans, der meddeler sig udefra til mennesker som et verbum externum. Gud er forskellig fra sin skabning, men også tæt forbundet med skabningen, som den trinitariske Gud står i levende dialog med. Derigennem bliver kirken til som en ny skabning ud af, midt i og på tværs af det af Gud oprindeligt skabte liv - og dermed bliver kirken Guds gave og udfordring til de historiske kulturer, vi mennesker lever $\mathrm{i}$ her og nu. På den måde er kirkens liv en deltagelse $\mathrm{i}$ Guds trinitariske liv: Her leves og gennemlyses det skabte liv, her udfoldes Guds åbenbaring af sig selv i Jesus Kristus, og her skaber Gud Helligånd nyt liv og fællesskab i og mellem mennesker, som tror på Jesus Kristus. Midt $\mathrm{i}$ alt dette virker teologien, der dermed bliver delagtig i Guds trinitariske bevægelse. Teologi er i denne prægnante forstand en distinkt kristen eller sågar kirkelig funktion - indfældet $\mathrm{i}$ Guds trinitariske fællesskab, sådan som mennesker inddrages i dette fællesskab. Det gælder ikke mindst for den praktiske teologi:

The Trinitarian theology of participation and mediation means that the cultural expressions of the Church are seen as a place of divine encounter (...) The communication of the Church can be read as culture but it is also and at the same time a place of divine indwelling (...) practical theology must locate itself as a spiritual discipline of rational and critical interaction with the expression of the Church (...) practical theology is also participation and mediation, which is to say an indwelling and being indwelt. Practical theology is theological because it is reflection (...) [and thus] mediation of and participation in the Trinitarian life of God (Ward 2008, 98-99 og 104).

Som teologien i prægnant forstand må reflektere kirkelig og kristen praksis, må praksis lade sig belyse af teologien. Det gælder særligt for den praktiske teologi, der på én gang må være tæt på den kristne og kirkelige praksis og udrustet med omfattende indsigt fra hele teologiens område. Vi har brug for en empirisk informeret teologi, hvor den empiriske virkelighed kan udfordre - og lade sig udfordre af - teologien fra vores traditioner. Vi har brug for et luthersk lex orandi lex credendi. Ligesom Prosper af Anquitaine (390-463) ved vi noget fra den daglige kristne praksis. I hvad der siges og gøres i kirkens liturgi og bønner, har vi værdifulde kilder for teologien, idet bønnens 'regel' kan og skal danne rygrad i troens 'regel' ut legem credendi lex statuat supplicandi, som Prosper udtrykker det (Lathrop 1994, 38). Generelt har det været sådan, at den ortodokse kirkes teologi er liturgi, den katolske kirke har en teologi om liturgien (jf. Irwin 1994), mens i 
hvert fald den danske lutherske kirke har knyttet til ved den lutherske Deutsche Messe-tradition fra 1526, der kan læses, så liturgien, der kaldes "ceremonier", reduceres til historisk forhåndenværende bærere af den foreliggende "rette" teologi. Den form for adiaforisering af liturgien og den kristne praksis giver mere medløb end modstand til vores sekulariserede tidsalder.

Det gælder for kirken og dens liturgi, som det gælder for al kristent liv: Tør vi ikke tolke det som et udtryk for Guds virke i og blandt os og som menneskers deltagelse $i$ og bidrag til kommunikationen af Guds trinitariske liv, har vi allerede omskabt den kristne Gud i deismens billede af Gud som den pensionerede urmager, sådan som teologien kun alt for flittigt har bidraget til det gennem snart 200 år (Taylor 2007, 221ff). Man kan i stedet arbejde med en teologi, der drives som en troende undersøgelse af det, hvorpå vi tror, som den unge K. E. Løgstrup (1905-1981) udtrykte det (Løgstrup 1938) - altså ud fra Anselms teologiske program: fides quaerens intellectum, som man kan følge uanset arten af ens tro. Dette bidrag forholder sig til kirken - og det i skikkelse af de nordiske folkekirker. Bidragets påstand er, at de har hårdt brug for en fuldtonende teologisk selvforståelse. Og bidragets forslag er, at vi til en sådan kan hente den stærkeste inspiration hos Grundtvig.

\section{Kirkeforståelserne i de nordiske folkekirker}

Den historiske baggrund og den kirkesociologiske situation bestemmer et langt stykke af vejen de nordiske folkekirkers teologiske selvforståelse (kirkesyn og ekklesiologi). Når man gennem mere end 1000 år har haft en kirke fra oven - med al initiativret hos kongen og gejstligheden - begynder kirkens medlemmer ikke fra den ene dag til den anden at tage kirkens ledelse og udvikling i egen hånd, som nogle forventer, at det skal ske fx ved menighedsrådsvalg i Danmark. Når man altid har haft biskopper med en vis selvstændighed i forhold til staten og, som i Sverige og Finland, har haft kirkeråd i snart 150 år, er det ikke nogen unaturlig tanke, at kirken må kunne stå på egne ben. Når man har prøvet totalt at bryde båndet til staten, som den norske kirke gjorde det under nazistyret under Anden Verdenskrig, er det en selvfølgelighed, at folkekirken primært må bygge på "Kirkens Grunn", som den norske kirkes løsrivelsesdokument fra 1942 hedder. Når man aldrig har oplevet en udtrædelsesbevægelse, går man langt for at holde sammen på kirkens fløje, som vi ser det i Danmark, hvor der er udstrakte mindretalsrettigheder for modstandere af kvindelige præster, gengifte og homoseksualitet, mens man i den svenske kirke kræver, at 
alle ansatte retter ind efter kirkerådets afgørelser. Overalt er vi tilbøjelige til at følge de kendte stier og gøre, som vi plejer, hvad vi nok også er bedst til, skønt det ikke nødvendigvis er det, der er mest brug for (Iversen 2012).

Både stiafhængighederne og de teologiske inspirationskilder er og har altid været mangeartede $\mathrm{i}$ alle de nordiske lande. Kirkernes teologiske selvforståelse kan derfor heller ikke sættes på en enkelt formel i hverken den ene eller den anden af de nordiske folkekirker, hvor mange teologiske tendenser trives side om side. Men vi kan opstille en grundmodel til afprøvning af de teologiske tendenser i de nordiske folkekirker. Modellen tager udgangspunkt i den kristne lære om den treenige Gud og kirkernes vægtning af denne lære i deres selvforståelse, eller udtrykt med Grundtvig: forholdet mellem den første og den anden skabelse:

Evangeliet (Præsteembedet) Jesus Kristus

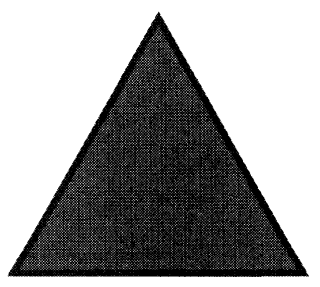

\section{Modtagelsen \\ (Menigheden) Helligånden}

\section{Folket \\ (Servicekirken) \\ Gud Fader}

Figur 1: Trinitarisk folkekirkeekklesiologi

Folkekirken forudsætter for det første en tro på Gud som alle menneskers skaber. I tiltro til Guds skabelse kan folkekirken gå ud fra, at alle mennesker har hjertet på rette sted. Derfor må de være velkomne og kan bruge kirken og bruges i kirken, som de er. Der er således gode skabelsesteologiske grunde til, at folkekirken må være en åben kirke. Man kan imidlertid i en folkekirke - ikke mindst i et velfærdssamfund - få den tanke, at kirken alene er til for at servicere mennesker med, hvad de nu har brug for. Tanken om servicekirken kan med andre ord komme til at skygge for troen på, at alle mennesker er skabt i Guds billede - til og ved Jesus Kristus.

Folkekirken forudsætter for det andet, at Guds kærlighedshandling ved Jesus Kristi fødsel, liv, død og opstandelse, er sket, fordi Gud elsker "verden", dvs. alle mennesker og ikke bare de specielt kirkelige. Dermed er folkekirkens hovedopgave den at gøre Jesus Kristus kendt, troet og efterlevet blandt alle mennesker. Overalt må kirken i ord og 
handling søge at præsentere og repræsentere budskabet om Guds kærlighed i Kristus blandt alle slags mennesker. Folkekirken kan imidlertid - ikke mindst, hvor den er statskirkelig - få den tanke, at alt står og falder med præsteembedet, som jo værner om Guds åbenbaring og evangelium. Den formale vægt på præstens forkyndelse og sakramenteforvaltning risikerer med andre ord at skygge for, at det er Guds kærlighed til mennesker, der skal komme til udtryk og have skikkelse i kirken, ikke fremhævningen af præsterne som en særlig stand med et praktisk monopol på mediering mellem Gud og mennesker.

Endelig forudsætter folkekirken for det tredje troen på Helligånden som den skaberånd, hvormed Gud skaber nyt i dag. Helligånden skaber troen, Kristus-tillidens modtagelse, i menneskers hjerter, og dermed skaber den det kristne fællesskab i og ud fra kirken. Kirken er derfor ikke kun en menneskelig foranstaltning, men et fællesskab i et nyt folk ud af, midt i og på tværs af alle folk. Folkekirken kan imidlertid - ikke mindst $\mathrm{i}$ en situation med få og små grupper af aktive kristne midt i en stor mængde passive medlemmer - få den tanke, at alt står og falder med ret liv og lære i menighederne. Menighedernes signal "Kom, som du er, og bliv som os" risikerer med andre ord at blænde af for, at det er den treenige Gud og ikke en bestemt form for menighedsliv, der er kristendommens centrum.

Der er ikke så ligetil at holde balancen i denne trinitariske trekant. I Sverige har man i mere end 100 år søgt at gøre op med en ufolkelig embedskirkelighed, først ved med Einar Billing at fremhæve, at kirken skal struktureres som national folkekirke ud fra den kristologiske tanke, at Guds nåde altid er til stede forud for menneskers gøren og laden (gratia praeveniens). I anden omgang har man i stedet fokuseret på servicekirken - folkekirken som "tjänstproducent i välfärdssamhället" (jf. Vikström 2008). Samtidig arbejdes der med gudstjenestecentreret menighedsopbygning (Modeus 2005), hvor den svenske kirke bevæger sig fra at være kirke for til også at ville være kirke ved og af folket, for så vidt man deltager i menighedens gudstjeneste. I Norge har man i de seneste årtier bevæget sig fra en pietistisk fromhedsprofil med megen vægt på livet i "bedehusene" til en mere folkekirkelig tankegang, der bl.a. kommer til udtryk i, at "den norske kirke" omdøbes til "den norske folkekirke" i den nye grundlov fra 2013 (Hegstad 2009). Det sker parallelt med en satsning på lokal menighedsudvikling (Birkedal m.fl. 2011). I Finland fastholdes kirkens og præsternes forpligtelse på kirkens traditionelle lære på en måde, så det nu fører til store mængder af udmeldelser, selv om kirken i øvrigt er præget af en ganske bred vifte af moderne arbejdsformer (Niemelä 2007). I Danmark har en ensidig vægtning af skabelses- 
tanken hos Morten Pontoppidan fort til mange årtiers polemik mod enhver form for menighedsdannelse eller fromhedsliv, ud fra den tanke, at "den levende Guds menighed" er det geografisk afgrænsede, Gudskabte sogn, så enhver tale om (selvbestaltede) "levende menigheder" i virkeligheden er ukristelig (Iversen 1987, 109-139). Dermed negligeres både nødvendigheden af "identifikation af kirken" og den indsigt, at "ånd har krop" (Aagaard 1991 og 2005), som nu er kommet stærkt på dagsordenen i de senere år (jf. Bollman m.fl. (red.) 2002) på en måde, så folkekirkelige og frikirkelige kirkesyn er kommet betydeligt tættere på hinanden i de seneste årtier (jf. Fahlgren m.fl. (red.) 1998).

I begyndelsen af forrige århundrede proklamerede den tyske biskop Otto Dibelius et Jahrhundert der Kirche i en situation, hvor de fleste europæiske kirker stod midt i selvstændiggørelse fra staten - og således med et akut behov for at definere en kirke, der er andet og mere end statens forlængede arm. Først med Anna Marie Aagaards bog Identifikation af kirken fra 1991 er denne debat rejst i den danske folkekirke. Det er ikke klogt at springe ud i noget nyt uden at kende sin historiske baggrund. Der er heller ikke tilrådeligt at tænke i nye kirkeformer uden forankring i den teologiske tradition, kirken har med sig. Det er Grundtvigs bidrag til den folkekirkelige tradition, vi nu vender os mod.

\section{Den første skabelse i Grundtvigs trinitariske teologi}

Når man som dansk teolog er i international teologisk sammenhæng, savner man ofte en klarere trinitarisk teologi eller rettere: en teologisk tænkning, hvor skabelsesteologien står markant i trinitarisk teologisk sammenhæng. Skabelsesteologiens stærke stilling i dansk teologi skyldes især Grundtvig, og den er $\mathrm{i}$ det 20 . århundrede forvaltet selvstændigt af K. E. Løgstrup i Danmark - som af Gustaf Wingren i Sverige. Den trinitarisk indfældede skabelsesteologi har stor betydning i den danske folkekirkes praksis og selvforståelse, dog kun sjældent $i$ den systematisk udarbejdede teologi. Det skyldes det historisk betingede træk i Grundtvigs teologi, at han har vanskeligheder ved selv klart at udfolde kirkeforståelsen trinitarisk, selv om hans kirkesyn nødvendigvis - implicit - er trinitarisk. Det er denne implicitte trinitariske ekklesiologi hos Grundtvig, vi nu skal eksplicitere.

Hos Grundtvig er "Gud først og sidst" (Bjerg 2002). Gud - og Gud vil hos Grundtvig altid sige den apostolske trosbekendelses trinitariske Gud - har hos Grundtvig i bogstavelig forstand the whole world in his hand, som det hedder i sangen. Gud skaber ikke blot i begyndelsen - 
eller ved fortsatte indslag i historien. Gud har skabt og skaber alting, inklusive historien. "Historien er en del af Guds skabning og står dermed $i$ et stadigt modsvarighedsforhold til Gud. Falder noget ud af dette forhold, falder det ud i intetheden”, siger Theodor Jørgensen helt på linje med Grundtvig (Jørgensen 1995, 48). Grundtvigs skabelsesteologi udfoldes ikke blot som en teori om magten bag bestemte livsytringer, men som en historieforståelse af universalhistorisk art, hvor alt kan og bør forstås teologisk - ud fra dets forhold til den trinitariske Gud, som alt beror på. Alt menneskeliv er udtryk for Guds kærlige, opretholdende og frelsende skabergerning. Alt er skabt til og ved Kristus, det skabende Gudsord. Det gælder den dag i dag, hvor "Helligånden skaber både sand menneskelig selvforståelse og kristen tro hos mennesket" (Grell 1988b, 313). Helligånden står ikke i modsætning til menneske- og folkeånden, som har deres liv fra samme hellige skaberånd. Tværtom må Helligånden for at kunne skabe Kristustro virke $\mathrm{i}$, med og under folkeånden, som $\mathrm{i}$ bogstavelig forstand er det "sit eget", som Kristus, den hellige ånds skaberord, kommer til i håb om at blive taget imod (Joh 1,11). Grundtvigs teologi, som har sit centrale omdrejningspunkt og grundstof fra Kristi egne levende ord i menighedens gudstjeneste, og som kun bruger Bibelen som oplysningsbog, udfolder et sammenhængende syn på livet fra skabelse til genløsning - fra 1. Mosebogs skabelsesberetning til Åbenbaringsbogen, med centrum i Johannesprologen. Siden Helge Grells disputats Skaberånd og folkeånd. En undersøgelse af Grundtvigs tanker om folk og folkelighed og deres forhold til hans kristendomssyn fra 1988 har der været overvejende enighed om den forståelse af Grundtvig i den teologiske forskning, selv om det er og bliver vanskeligt at arbejde med et så altomfattende teologisk projekt som Grundtvigs - i en sekulariseret tid som vores (jf. debatten i Schjørring (red.) 1988).

Kunne Grundtvig med denne massive skabelsesteologi ikke helt undvære Kristus og Helligånden - og $\mathrm{i}$ hvert fald kirken, kan man spørge? Eller er der i det særligt kristelige (Kristus, Helligånd, frelse og kirke) blot tale om dubleringer af ord for Skaberens gerning eller om andre ord for denne? Sådan kan man godt se på det, for Kristus er skabelsens virkende Gudsord, ligesom Helligånden er den samme Guds ånd som skaberånden i 1. Mosebog. Men Grundtvig tænker ikke så enkelt. Han tænker historisk - frelseshistorisk, om man vil. Grundtvig er, som de fleste i hans samtid, evolutionstænker. Alting undergår en udvikling - det kan man læse om i Bibelen, og sådan må man læse historiens store lærebog, som Grundtvig flittigt studerede og omskrev efter egne indsigter. Guds historie med menneskene kender Grundtvig 
- vigtigst af alt - også fra Herrens egne "Mundsord", den apostolske trosbekendelse, nadverens indstiftelsesord og Fadervor, som lyder til os fra Herren selv ved dåb og nadver i kirkens gudstjeneste (Prenter 1983 og Schjørring 1990). Her tegnes der et historisk forløb - et før, et nu og et til sidst, der alt sammen er til stede i gudstjenesten nu, i dag som i synagogen i Nazaret, da Jesus læste op af Esajas 61,1-2 (Luk 4,21, Schjørring 1987, 111-153).

Efter sin "mageløse opdagelse" af ordene af Herrens egen mund omkring 1825 er Grundtvig lige så meget åbenbaringsteolog som skabelsesteolog. Han opdager nemlig, at Kristus taler suverænt og nyskabende $\mathrm{i}$ den apostolske trosbekendelse, nadverens indstiftelsesord og Fadervor, der - som ord af Kristi egen mund - skaber den tro og den virkelighed, de selv nævner her og nu i kirkens gudstjeneste. I mundsordene taler og skaber Kristus selv, idet han $\mathrm{i}$ det ydre låner menighedens stemmer, så trosbekendelsen, indstiftelsesordene og Fadervor kan lyde. Dermed opstår der en dobbelthed eller en dialektik mellem den universalhistoriske skabelsesteologi og den særligt kirkelige åbenbaringsteologi hos Grundtvig. Som Helge Grell har peget på det (Grell 1988a, og 1988b, 243), tematiserer Grundtvig klarest den dialektiske dobbelthed, der kommer til udtryk i de to ligedannede skabelser, i følgende strofe fra salmen "Hvor skal jeg Guds Billed finde?" fra 1850/51:

Tak, vor Gud! for Mund og Mæle

Til det Ord, hvormed Du skiød

Liv og Lys i vore Sjæle,

Os din Kiærlighed indgiød,

Første Gang som Skaber god,

Mild ved Støvet for din Fod,

Anden Gang som Synds-Forlader,

Naadig Gud og kiærlig Fader!

(GSV IV, 277).

Megen strid i Grundtvigforskningen kan ses som en kamp om udlægningen af forholdet mellem de to skabelser, "Første Gang" og "Anden

\footnotetext{
${ }^{1}$ Ved forelæsningen i Uppsala stillede biskop emeritus Björn Fjärstedt det oplagte spørgsmål, om Grundtvig, der ellers tænker konsekvent trinitarisk om alt, ikke også kan tænke og tale om en tredje skabelse? I direkte forstand gør han det øjensynligt ikke, men holder sig - på god luthersk vis - til de to skabelser, som demonstreret i denne artikel. Ikke desto mindre taler Grundtvig også om en tredje "skabelse", som blot ikke kaldes "skabelse". Det sker ifølge Uffe Jonas, idet det menneskelige fra den første og det kristelige fra den anden skabelse indgår i en inderlig vekselvirkning eller sammensmeltning i menighedens skole for sang og i det kristeligt-ægteskabelige kærlighedsliv, hvor alle elementer,
} 
Gang". "Ordet", hvorved Gud indskyder menneskene liv, lyst og kærlighed, er skaberordet, Kristus. Som Kristus er den samme, er Skaberånd og Helligånd det også. Kristus er "den dybe Sammenhæng" i alting, som det hedder i salmen "Hil dig, Frelser og Forsoner!" (GSV I, 456). Ordet, Kristus er altings begyndelse og ende (jf. salmen "I Begyndelsen var Ordet", GSV V, 327-340, og Schjørring 1999). Tilsvarende er folkeåndens ophav i Guds hellige skaberånd "Nøglen til mine Gjemmer (...) Lede-Traaden i min Troi-Borg" (Grundtvigs Literaire Testamente, 1827, US V, 176). Her finder vi det teologiske udgangspunkt for Grundtvigs programmatiske ønske om samarbejde med "Naturalister (...) alle Mennesker med Aand", der deler hans grundlæggende "Mosaisk-Christelige Anskuelse" (Nordens Mythologi, 1832, US V, 401) af livet som skabt. På det grundlag kan der drives skole, laves universitet og føres regering sammen med fx jøder, sådan som diskussionen stod om det på Grundtvigs tid. Som skabte har alle mennesker adgang til forståelsen af at være et guddommeligt eksperiment af krop, sjæl og ånd (jf. 408), gjort i Guds billede. Her findes det fælles menneskelige, som ikke blot er en kronologisk og en epistemologisk forløber for den kristentro, der pædagogisk må bygge videre på det før-kristne menneskelige. Det menneskelige, sådan som det altid udfoldes i historisk og kulturelt bestemte folkelige liv, er et teologisk bestemt, gudskabt, grundlag for kristendommens virke. Det er baggrunden for Grundtvigs ofte programmatisk tolkede, om end kun posthumt offentliggjorte - og også ofte afteologiserede - digt:

Menneske først og Christen saa,

Det er et Hoved-Stykke,

Christendom vi for Intet faae,

Det er den pure Lykke,

Men Lykke, som kun times den,

Der alt i Grunden er Guds Ven

Af Sandheds ædle Stamme!

Stræbe da hver paa denne Jord

Sandt Menneske at være

Aabne sit Øre for Sandheds Ord,

Og unde Gud sin Ære;

Er Christendom da Sandheds Sag

Om Christen ei han er i Dag

Han bliver det i Morgen!

(GSV III, 297-298).

inkl. det feminine og det maskuline, forenes i, hvad der på engang er en filosofisk forstået visdom og en teologisk forstået eskatologi, hvor Kriste-Ligheden udfoldes helt i Helligåndens kraft (Jonas 2007). 
Som mennesker må tage udgangspunkt i det gudskabte menneskeliv i hus og folk, de er skabte til, må kirken også gøre det. Den må med andre ord stræbe efter at være menneskelig og folkelig, akkurat ligesom de mennesker, kirken skal arbejde iblandt, er det.

\section{Den anden skabelse i Grundtvigs trinitariske teologi}

Frelsen i Guds anden skabelse fastholder, fortsætter og foregår på grundlag af den første skabelse, som gælder alt menneskeliv. For Grundtvig er Guds inkarnation, menneskevordelsen i Jesus af Nazaret, et afgørende bevis for, at Gud vedstår sin første skabelse. "Det er (...) den 2. trosartikel, der begrunder Grundtvigs udfoldelse af den 1. trosartikel" (Jørgensen 1988, 18). Grundtvigs teologi er derfor inkarnatorisk og kropslig indtil det materialistiske (Iversen 2008, kap. 1). Gud kunne have skabt sig en ny verden og et nyt menneske, men det gør han ikke. Han genskaber og skaber derved midt i den gamle skabelse, ja, faktisk mens den endnu finder sted. Selv om synden har tilstøvet og til dels forkrøblet den første skabelses værk, er de tre afgørende komponenter til stede som forudsætninger for genskabelsen. Mennesket har nemlig fortsat del $\mathrm{i}$ den ånd, den livsånde, som Gud indpustede $\mathrm{i}$ det ifølge 1. Mosebog 2,7. Og mere endnu, mennesket har også talens brug, ordet, det lille ord, som er et aftryk af det store skaberord, hvormed Gud skabte alting ifølge 1. Mosebog kap. 1. Ånd og ord kan imidlertid misbruges ganske forfærdeligt, men mennesker har også overalt fra barnsben i huslivet en klar sans for kernen, kraften og kriterierne i det gode menneskeliv, som for Grundtvig består i den paulinske triade, tro, håb og kærlighed (Iversen 1987, 92f.). Hos alle mennesker finder vi ifølge Grundtvig skabelsens gudbilledlighed intakt i form af tre elementer: ånden, ordet og triaden tro, håb og karlighed. Derfor kan der midt i det menneskelige nyskabes et kristeligt liv, sådan som det ifølge Grundtvig sker, når Jesu Kristi egne skabende ord lyder i kirkens gudstjeneste.

For Grundtvig har den anden skabelse solide forudsætninger i den første. Og dog er der tale om Guds suveræne nyskabelse - den har karakter af åbenbaring. Intet menneske kunne tænke sig til den, kun længes efter den som efter den overraskelse, Guds handling altid er. En vag deistisk skabelsesteologi, som var fremherskende i samtidens rationalistiske teologi, kunne Grundtvig ikke leve af. Hvor Luthers for reformationen afgørende spørgsmål var: "Hvor finder jeg en nådig Gud?", er Grundtvigs eksistentielt afgørende spørgsmål: "Hvor finder jeg en nærværende Gud?” (Iversen 2008, kap. 5). Grundtvig kan ikke være kristen uden erfaring af Gud, uden vished i troen, uden kriterier 
for kristen identitet og uden, at der er autoritet bag kilden til kendskabet til Gud. For Grundtvig må kristentroen på engang bygge på erfaring og åbenbaring (Jørgensen 1995, 177ff.). Her er den rationalistiske teologi ikke til megen hjælp, hverken for Grundtvig, for menigmand eller de frembrydende gudelige vækkelser. I samtidens teologi fremstilledes den kristne kirke som "saa lidet activ, saa ørkesløs som mueligt", idet man kun byder på "en død Mands Aand, paa hvis Kraft i Læren den skulde stole, men hvis Lære den maatte lade godt Folk selv giætte sig til" (US IV, 409). For Grundtvig, der omsider fik fast præsteembede fra 1821, var det håbløst at slås med den rationalistiske teologi og den nye historisk-kritiske bibellæsning. Her kommer hans mageløse opdagelse af de ord af Herrens egen mund, der er "forplantet fra Mund til Mund og fra Slægt til Slægt, som hans egen Munds Ord, der aldrig maa vige fra hans Menigheds Mund, og hvorfra hans Aand aldrig kan vige" (US IX, 333), ind i billedet som den guddommelige indskydelse, der fra 1825 bliver hovedhjørnestenen i Grundtvigs teologi, kirkesyn, forkyndelse og salmedigtning. Så meget fremhæver Grundtvig i alle sine kirkelige og teologiske skrifter Kristi nærvær og virke i gudstjenesten, at han fra nu af kan læses som åbenbaringsteolog af næsten højkirkelig tilsnit, som $\mathrm{fx}$ anglikaneren Donald Allchin tenderer mod at gøre det (Allchin 2000, 106-116, jf. også Schjørring 1987, 56ff., og Grell 1995). Men Grundtvigs lærebygning, som han selv kalder sin teologi, er fortfarende trinitarisk - med Herrens mundsords åbenbaringskarakter og den ved Helligånden skabte kristentro tæt forbundet med grundlaget i den første skabelse.

Hvad sker der med os, når Gud gennem Kristus taler i gudstjenestens trosbekendelse, Fadervor og indstiftelsesord, og vi siger ja dertil? Ja, så skabes i os det nye liv, som kendes gennem livsudtrykkene tro, håb og kcerlighed, og så ytrer troslivet sig uvilkårligt i de livstegn, som kun findes hos den troende menighed: forkyndelse, bekendelse og lovsang. I de senere kapitler af Den Christelige Børneloerdom begynder Grundtvig at systematisere dogmatikken, idet han taler om "en kristelig Lærebygning", der kunne være "en Tegning til det ny Jerusalem" (US IX, 470 og 479). Selv udlægger han dog ikke tegningen ganske klart og aldrig i skematisk form. Grundtvig kredser omkring kirkeforståelsen i Børnelærdommens kap. 5 "Om vor tredje TroesArtikel" og især i det sidste lange kapitel 21 om "Det evige Livs Ord af Vorherres egen Mund til Menigheden". Grundtvigs mest instruktive prosatekst om kirken er det første kapitel af Kirkelige Oplysninger iscer for Lutherske Christne (US VIII, 370-406). Tegningen kan se således ud (Iversen 2008, kap. 5): 


\begin{tabular}{|l|l|l|l|}
\hline Livsord/mundsord & Trosbekendelse & Fadervor & Indstiftelsesord \\
\hline Livsudtryk & Tro & Håb & Kærlighed \\
\hline Livstegn/kirkekendetegn & Bekendelse & Forkyndelse & Lovsang \\
\hline Treenigheden & Helligånden & Sønnen & Faderen \\
\hline Guds rige & Retfærdighed & Fred & Glæde \\
\hline Eskatologien & $\begin{array}{l}\text { syndernes } \\
\text { forladelse }\end{array}$ & $\begin{array}{l}\text { kødets } \\
\text { opstandelse }\end{array}$ & det evige liv \\
\hline Mennesket & And & Sjæl & Krop \\
\hline Mennesket udvortes & Hånd & Mund & Hjerte \\
\hline Mennesket indvortes & Livskraft & Sandhed & Kærlighed \\
\hline
\end{tabular}

Figur 2: Grundtvigs kristelige lærebygning

Andre - fx Svend Bjerg $(2002,51)$ - tegner Grundtvigs dogmatiske bygning anderledes og tager eventuelt flere led ind. Det ovenstående er imidlertid nok til at illustrere Grundtvigs kirkesyn. Kirken er den nyskabende kommunikation, der sker, når livsordene skaber livsudtrykkene, som ytrer sig i livstegnene, som umiskendeligt er tegn på, at her har vi at gøre med Jesu Kristi kirke. Samtidig gentager livstegnene, bekendelsen, forkyndelsen og lovsangen, der er menneskers respons på det nye liv i kristen tro, håb og kærlighed, så at sige livsordene, som således gives videre til andre mennesker til liv og tro. Først og sidst er det dog Gud, Helligånden, Sønnen og Faderen, der handler i og med denne kirkens indre kommunikation. Grundlæggende tænker Grundtvig altid teologisk (Grell 1988b, 317-320). Og midt i det udfoldes Guds Rige og foregribes den endelige frelse, som den bekendes i trosbekendelsen. Når menneskene kan indgå i denne kommunikation, skyldes det, at de er skabt treenige i den treenige Guds billede: Mennesket er udrustet med ånd, sjæl og krop, med hånd, mund og hjerte - og med kraft, sandhed og kærlighed (jf. Iversen 2008, kap 2). For Grundtvig flyder kirkens, frelsens og menneskelivets trefoldige struktur ud af Guds treenighed. I poetisk form finder vi skemaets centrale dele i salmen "Midt iblandt os er Guds Rige" fra 1853:

Midt iblandt os er Guds Rige

Med Guds Aand og i Guds Ord,

I Guds Menighed tillige:

Giæster ved Hans Naadebord!

Synligt ei er her tilstæde

Det med Guds Retfærdighed,

Med Guds Fred og Herrens Glæde,

Kommet til os ovenned. 
Thi den gode Jord hernede:

Tro og Haab og Kiærlighed, Rense vil Gud selv og frede

Til en himmelsk Frugtbarhed!

(GSV IV, 344-345, str. 1-2 og 8)

Rensningen af den medskabte tro, håb og kærlighed er, hvad Gud bruger kirken til at være kanal for. Dette produkt af den anden skabelse hører lige så vel som produktet af Guds første skabelse til, hvad Grundtvig kalder "Kiendsgierninger" $(V U \mathrm{~V}, 388)$. At Gud virker i sin anden skabelse ved, at Kristus siger sine skabende mundsord på menighedens tunger, er Grundtvigs "mageløse opdagelse", som der kan arbejdes teologisk videre med den dag i dag (Jørgensen 1995, 177196, og Iversen 2008, kap. 5). I den anden skabelse opstår der ny tro, håb og kærlighed med Kristusorientering i kraft af en vækst, der foregår som en rensning, fredning og styrkelse af den menneskelige tro, håb og kærlighed. Men det sker midt i den første skabelses menneskeliv, som leverer materialet til genskabelsen i den anden skabelses nye liv. "Menneskeordet er og forbliver genlydsord af Gudsordet" (Jørgensen 1995, 24). Det menneskelige og det kristelige er dybt kompatibelt:

Menneske-Livet $[e r]$ i sin allerdunkleste, sin allerfattigste og allerureneste Skikkelse dog i Grunden (...) af samme Art, som Menneske-Livet i sin allerrigeste, allerreneste og allerklareste Skikkelse, saa at - for at sige alt med eet Ord - Røveren paa Korset havde samme MenneskeLiv til fælles med Guds enbaarne Søn, Vorherre Jesus Kristus, til hvem han raabte: Herre! tænk paa mig, naar du kommer i dit Rige! (Den Christelige Børnelcerdom, US IX, 429).

Så stærk er Grundtvigs tillid til den første skabelses gudbilledlighed hos alle slags mennesker, at han fremhæver det ærlige i det sandt menneskelige hos ikke-kristne, altså hedninger, frem for det vanemæssigt kristelige. Det sker fx i omtalen af den kvindelige forfatter til Danmarks første kvindekampskrift, romanen Clara Raphaels Breve, som han 24. maj 1851 anmeldte positivt i Danskeren IV (US IX, 288293, og $V U \mathrm{~V}, 402-407)$ :

da man altid maa være et levende Menneske først, for at blive en levende Christen, saa er Clara aabenbar Guds Rige langt noermere end baade Prasten, der skrifter, og Frøkenen, der vil omvende hende, uden endnu at have hendes levende Følelse af, hvad Mennesket, skabt $i$ Guds Billede, selv under sit dybeste Fald er og maa være baade i Guds og sine egne Øine (US IX, 291, VUV, 406). 
Grundtvig indrømmer gerne, at det er vanskeligt at lave klare skillelinjer mellem det hedenske og det kristelige $\mathrm{i}$ og hos danskerne, fordi de to dele, hidrørende fra hver sin skabelse, dog lever i og med de samme mennesker ("Hedenskab og Christendom i Danmark", Danskeren 1851, 82-96). Også agnostikeren Bertel Thorvaldsen, der som billedhugger blandt andet skabte den store Kristusstatue til Frue Kirke i København, kan Grundtvig stille sig lige med ud fra værdsættelse af - og slet skjult stolthed over - den første skabelses hedenske liv, sådan som det sker i mindedigtet over Thorvaldsen fra 1844 (først trykt i 1848):

Jeg korser mig for lede "Satan" kun,

Og ei for Mennesker, som mine Lige,

Jeg selv var Hedning, men dog ingen Hund,

Og Skriftemaalet mit i Sandheds Rige,

Det lyder saa: det randt mig nys ihu,

At der er meget Hedenskab hos mig endnu!

(US IX, 12).

\section{Det trinitariske i folkekirken}

Grundtvig var hele sit liv på kant med først statskirken og fra 1849 folkekirken. Præsternes rutinemæssige forpligtelser for slet ikke at tale om den altid nærværende fare for, at Grundtvigs kirkesyn skulle blive marginaliseret eller umuliggjort, $\mathrm{fx}$ gennem påtvungne ritualændringer, betød, at han fra 1839 til sin død i 1872 klamrede sig til sin frie præstetjeneste på fattigstiftelsen Vartov, hvor han reelt fungerede som valgmenighedspræst for en kreds af tilhængere - længe før valgmenighedsloven af 1868. Selv om Grundtvig ikke var uberørt af vennernes tilbud til ham om at blive leder af en fri menighed uden for statskirken, var det umuligt for ham at forlade den fælles kirke. Som skabelsesteolog er han udpræget folkeligheds- og folkeslagsteolog. Kristendommens historie er for Grundtvig at se folkeslagskirkernes historie, sådan som han udfolder det i det store portræt af de syv folkemenigheder i Christenhedens Syvstjerne fra 1860. Folkekirkerne er således helt i kristendommens ånd ifølge Grundtvig. Tættest på en tilslutning til den ved grundloven af 1849 forordnede "evangelisk-lutherske Folkekirke" $(V U \mathrm{~V}, 381)$, kommer han i artiklen "Folket, Folke-Kirken og FolkeTroen i Danmark", der blev trykt i Danskeren 1851. Selv om Grundtvig havde stemt imod denne udtryksform til grundlovens paragraf 4, tager han den i 1851 som en kendsgerning, dog i sin egen specielle fortolkning.

Grundtvig kritiserer i artiklen voldsomt den ufrihed, som folkekirkens medlemmer er udsat for, når der trods grundlovens principper 
om trosfrihed fortsat er borgerlige følger af medlemmernes adfærd i forhold til dåb, konfirmation, bryllup og altergang. Når man argumenterer for, at den fortsatte kirketugt skal sikre, at vi ikke får "Hedninger" i Danmark, slår Grundtvig fast, at hedenskab jo blot er, hvad folket har levet med "fra Arildstid (hedenifra)", så det langt er at foretrække frem for enhver form for tvang i trossager ( $V U \mathrm{~V}, 393)$. Undervejs støtter Grundtvig sin argumentation på grundlovens udnævnelse af statskirken til folkekirke, som han - noget i strid med grundlovens $\S 4$ - forstår som "en fri Folke-Kirke" (VU V, 393), helt uden bekendelses- og sognetvang både for lægfolk og præster. Undervejs formulerer han tre praktisk teologiske handlingsanvisninger for en kirke, der vil være folkekirke og dermed respektere folkets liv som gudskabt udgangspunkt:

Kirken er til for Folkets Skyld og ikke Folket for Kirkens (VU V, 379).

Navnet "Folke-Kirke" er den tommeste af alle Titler, naar Kirken ikke i det Hele tiltaler og tilfredsstiller Folke-Hjertet (VU V, 389).

Naar man (...) ved borgerlig Troes-Frihed helbredes for det Vanvid med verdslige og haandfaste Midler at ville giøre sin Tro og aandelige Synsmaade herskende i en vis større eller mindre Kreds, da taber man derved ingenlunde den Lyst man har til at giøre sig og sit giældende $\mathrm{i}$ saa stor Kreds som mueligt, men da stikker man smukt Fingeren i Jorden og lugter sig til hvor man er, da stræber man baade ret at kiende det Folkefærd, man aandelig og hjertelig vil virke paa, og at faae Folkets Modersmaal i sin Magt, som det store Drivehjul, og endelig at oplyse Folket om sig selv og alt sit eget, da det kun er derved, man især vinder Folk og sikkrer sig Besiddelsen ( $V U \mathrm{~V}, 392)$.

Dette skabelsesteologisk begrundede (praktisk teologiske) program udfoldede og praktiserede Grundtvig kun selv i begrænset omfang (Iversen 1987, 75-107). Men det er blevet stående som en udfordring i dansk kirkeliv, ikke kun i kraft af formuleringer som ovennævnte, der oftest er overset, men nok så meget i kraft af hele den placering, som skabelsesteologien har i Grundtvigs trinitariske kristendomsforståelse, som $\mathrm{i}$ dag kendes fra, men ikke nødvendigvis forstås gennem hans hyppigt sungne salmer. Som eksempel kan nævnes "Himlene, Herre, fortælle din Ære" (GSV I, 282-283), hvor den Gudsindsigt, som det skabte formidler, vikles sammen med den forklarelse og oplysning af indsigten fra den første skabelse, som vederfares os, når Ordet, Kristus, i den anden skabelse fører mennesker til livet og gør "Viismænd (...) af vankundige Smaa!".

Forholdet mellem den første og den anden skabelse føres også igennem i Grundtvigs syn på forholdet mellem præsteembedet og 
menigheden. Det viser sig fx i Grundtvigs meget brugte ordinationssalme "Idag, paa apostolisk Viis" (GSV III, 475). Der er tale om en fuldtonende epikletisk ordinationssalme, med bøn om udrustning fra sandhedens ånd, så de ordinerede kan blive "en Vidne-Krands!" (GSV VI, 258). Der siges imidlertid intet om, at indvielsen gælder en særlig stand, fx præster. Salmen kan derfor med føje bruges såvel ved bispeog diakon- som ved præsteindvielse. Ja, den kan bruges ved enhver lejlighed, hvor en tjener indsættes i sin tjeneste - fx som kirkeligt ansvarligt menighedsrådsmedlem. På den måde er det tydeligt, at der på luthersk vis - skal forkyndes og forvaltes nådemidler i kirken, ligesom der i det hele taget må være et menighedsfællesskab i kirken, som Grundtvig forstår den, men det skabelsesteologisk bestemte udgangspunkt, hvor alle er lige nær på Gud, betyder for Grundtvig, at der ikke tales om en særlig gejstlig stand i kirken, selv om han - selv præst og barn af en gammel præsteslægt - forudsætter, at der i praksis fortsat tages præster til tjeneste i kirken. Den lutherske lære om alle døbtes lige stilling coram Deo uden mellemmænd får således hos Grundtvig en ekstra skabelsesteologisk begrundelse.

Kirken kan have sin ordning, fx med præster, men kirken står og falder ikke med en bestemt ordning, men derimod med, om muligheden for mundsordenes frie brug er sikret, så Gud selv kan skabe sin kirke af levende stene i og mellem mennesker - fuldt så frit i den anden som i den første skabelse. Grundtvigs mest afrundede kirkesynssalme "Kirken det er et gammelt Huus" fra 1836 slutter i SangVoerket med det kirkesynsmæssigt programmatiske vers, der indledes med en profeti om, hvad Grundtvigs kirkesyn skal komme til at betyde i Norden:

Aldrig dog glemmes meer i Nord

Kirken af levende Stene,

Dem som i Kraften af Guds Ord

Troen og Daaben forene!

Selv bygger Aanden Kirke bedst,

Trænger saalidt til Drot som Præst,

Ordet kun helliger Huset!

(GSV I, 81)

De officielle salmebøger, hvis kommissioner som regel har bestået af kongetro smådrotter og præster, har - som også den seneste danske salmehåndbog - opfattet næstsidste linje som polemik mod statskirkeligheden (Kjærgaard 2003, 336f.). På samme måde har man kunnet se et anarkistisk træk i det - luthersk set superkorrekte - udsagn i sidste linje, som åbner muligheden for, at valgmenigheder m.fl. kan indvie deres egne kirker blot ved at holde gudstjeneste i den uden en biskop- 
pelig indvielse af kirken. Den negative formulering hos Grundtvig er imidlertid (primært!) tænkt som et positivt udtryk for, at almindelige mennesker kan lægge stemmer til de mundsord, hvorigennem Helligånden skaber og Ordet helliger kirken - uden mellemmænd. ${ }^{2}$ På grund af den negative tolkning har strofen aldrig været med i en officiel salmebog før i 2003, hvor man fulgte et kompromisforslag fra 1976 ved at danne en ny salme af den hidtidige slutstrofe plus Grundtvigs slutstrofe, nu nr. 329 i Den Danske Salmebog. I denne korte form er salmen desværre ubrugelig - og oven i købet er der sket det, at Højskolesangbogen, som hidtil har haft Grundtvigs slutstrofe med, nu er gået over til at følge Den Danske Salmebog, hvad angår salmernes skikkelse, så slutstrofen nu heller ikke findes i Højskolesangbogens 18. udgave fra 2006. Helt godt står det altså ikke til med forståelsen af og pladsen til Grundtvigs fuldtonende trinitariske kirkeforståelse i hans eget fædreland.

\section{Grundtvig som modeltænker i nordisk teologi i dag}

Den form for "teologi, som deltagelse i kristen praksis", som her indledningsvis er anslået med et citat af Pete Ward og dermed de angelsaksiske bevægelser omkring Fluid Church, Emerging Church og Fresh Expressions of Church, praktiserer Grundtvig på sin egen førsekulariserede måde. Grundtvig driver sin teologi som led i sit enorme engagement i samtidens folkelige og kirkelige praksis - i protest mod den rationalistiske teologis sekularisering med deistisk nedskrivning af den trinitariske Gud.

I dag er sekulariseringen et livsvilkår (Iversen 2010). Vi lever, som om Gud ikke er til - eller i hvert fald, som om Gud er faldet aldeles permanent i søvn. Sådan kan man imidlertid ikke drive kristen teologi. Teologi må - som hos Grundtvig - drives som et forsøg på at tyde og tolke, hvad Gud taler til og gør i folk og kirke i dag (jf. ApG kap 2-3). Det er her i menneskers historiske liv, vi har de teologiske udsagns findested, locus theologicus (Aagaard 1973, 243ff. og 1976, 63). I det lys kommer vi også til at omtænke Regin Prenters og traditionens distinktion mellem primær teologi i liturgien og sekundær teologi som refleksion over historien og menneskelivet ud fra den primære teologi.

\footnotetext{
${ }^{2}$ Så lidt som der her ligger en polemik mod kongen, hvem Grundtvig altid var loyal over for, ligger der her en kritik af præsterne. Præstens samliv med menigheden sammenligner Grundtvig i 1851 med sin egen fuldkomne ægteskabelige forening med Marie Toft, idet de to "Os føle viet sammen, / Som Kirken og dens Amen, / Som Præst og Menighed!" (PS VII, 475, jf. Højskolesangbogen, 18. udgave, 2006, nr. 438, str. 1).
} 
Distinktionen holder som påvist af Helge Grell ganske enkelt ikke på Grundtvig (jf. Grell 1988c, 91f.). Den første og den anden skabelse er lige "primære", de er i lige grad udtryk for Guds handling - og må trinitarisk - tolkes i lyset af hinanden, ligesom de sekundære teologiske refleksioner over de to former for primær teologi må det. Skematisk kan man sige, at Gud taler primært, men forskelligt i de to skabelser, som begge $\mathrm{i}$ anden omgang kan gøres til genstand for (sekundær) teologiske refleksion.

\begin{tabular}{|l|l|l|}
\hline Primar teologi & Skaberordet/skabelsen & Mundsordene i liturgien \\
\hline Sekundaer teologi & Refleksion over det skabte & Refleksion over liturgien \\
\hline
\end{tabular}

Figur 3: Forholdet mellem de to skabelser og den primære og sekundære teologi hos Grundtvig

Akkurat til det formål at fastholde en ligelig vægtning af den første og den anden skabelse i såvel den primære som den sekundære teologi er Grundtvig den bedste læremester og modeltænker, vi har i de nordiske kirker. ${ }^{3}$

\section{Forkortelser}

Danskeren I-IV: N. F. S. Grundtvig (1848-51), Danskeren. Et Ugeblad, I-IV, København.

GSV I-VI: Th. Balslev (udg.) (1944-64), Grundtvigs Sang-Vark. Samlet Udgave, I-VI, København.

Højskolesangbogen: Højskolesangbogen. Attende Udgave (2006), København. PS I-IX: Svend Grundtvig m.fl. (udg.) (1880-1930), N. F. S. Grundtvigs Poetiske Skrifter, I-IX, København.

US V og LX: Holger Begtrup (udg.) (1904-09). Nik. Fred. Sev. Grundtvigs Udvalgte Skrifter, I-X, København.

VU, I-X: Georg Christensen og Hal Koch (udg.) (1940-49), N. F. S Grundtvigs Varker i Udvalg, I-X, København.

\section{Litteraturliste}

\section{Verker af Grundtvig}

Grundtvig, N. F. S. (1825), Kirkens Gienmoele. US IV, 395-429.

\footnotetext{
${ }^{3}$ Professor Sven-Erik Brodd gjorde efter forelæsningen i Uppsala opmærksom på, at Gustaf Wingren antageligt er den nordiske teolog, der tænker klarest ud fra en lignende to-skabelsesmodel som Grundtvig, idet den anden skabelse hos Wingren dog på klassisk luthersk er bundet til forkyndelsen og sakramenterne og ikke som hos Grundtvig til mundsordene, jf. Uggla 2010.
} 
Grundtvig, N. F. S. (1827), Skribenten Nik. Fred. Sev. Grundtvigs Literaire Testamente, US V, 154-180.

Grundtvig, N. F. S. (1840-42), Kirkelige Oplysninger især for Lutherske Christne, US VIII, 370-460.

Grundtvig, N. F. S. (1851), "Clara Raphael”, US IX, 288-293, VU V, 402-407.

Grundtvig, N. F. S. (1851), "Hedenskab og Christendom i Danmark", Danskeren IV, 82-96.

Grundtvig, N. F. S. (1851), "Folket, Folke-Kirken og Folke-Troen i Danmark", $V U \mathrm{~V}, 378-394$.

Grundtvig, N. F. S. (1855-61), Den Christelige Børnelaerdom, US IX, 329595.

Grundtvig, N. F. S. (1860), Christenhedens Syvstjerne. København.

\section{Varker af andre forfattere}

Allchin, A. M. (2002), Grundtvigs kristendom. Menneskeliv og gudstjeneste, Aarhus.

Birkedal, Erling m. fl. (red.) (2011), Sammen i forandring. Refleksjoner om menighetsutvikling i folkekirken, Oslo.

Bjerg, Svend (2002), Gud først og sidst. Grundtvigs teologi - en loesning af Den Christelige Børneloerdom, København.

Bollmann, Kaj m. fl. (red.) (2002), Stedet og vejen. En antologi om menigheden nu og i fremtiden, København.

Den Danske Salmebog 2003, København.

Fahlgren, Sune m.fl. (red.) (1998), På spanning efter framtidens kyrka, Örebro.

Grell, Helge (1988a.), "Historiesyn, gudsordet og menneskeordet. Temaer i Grundtvigs skabelsesteologi", Teologisk Forum 4/1988. Tillag til Kristeligt Dagblad 25. april 1988.

Grell, Helge (1988b) "Replik", i Schjørring, Jens Holger (red.) (1988), 85101.

Grell, Helge (1988c), Skaberånd og folkeånd, København.

Grell, Helge (1995), Grundtvig og Oxforderne, København.

Hegstad, Harald (2009), Den virkelige kirke. Bidrag til ekklesiologien, Trondheim.

Højskolesangbogen. Attende Udgave (2006), København.

Irwin, Kein W. (1994), Context and Text. Method in Liturgical Theology, Collegeville, Minnesota.

Iversen, Hans Raun (1987), And og livsform. Husliv, folkeliv og kirkeliv hos Grundtvig og sidenhen, Århus.

Iversen, Hans Raun (2008), Grundtvig, folkekirke og mission. Praktisk teologiske vekselvirkninger, København.

Iversen, Hans Raun (2010), "Sekulariseringen som vilkår for kirkens arbejde", Dansk Teologisk Tidsskrift 1/2010, s. 1-24.

Iversen, Hans Raun (2012), Historical, sociological and theological Patterns in the Nordic Folk Churches. Foredrag på Sigtunastiftelsen den 28. november 2011 (under trykning). 
Jonas, Uffe (2007), "Kvinde-Evangeliet: Om Grundtvigs mandebilleder og kvindesyner", Grundtvig-Studier 2007, 168-193.

Jørgensen, Theodor (1988), “Treenighedsteologi og folkelighed", i Schjørring, Jens Holger (red.) (1988), 9-26.

Jørgensen, Theodor (1995), Korset $i$ altet, København.

Kjærgaard, Jørgen (2003), Salmehåndbog II. Salmekommentar til salmerne $i$ Den Danske Salmebog 2002, København.

Lathrop, Gordon W. (1994), "Knowing Something a Little. On the Role of the Lex Orandi in the Search for Christian Unity", i So we believe so we pray. Towards koinonia in worship. Udg. af Thomas F. Best and Dagmar Heller. Faith and Order Papers no. 171, Geneva.

Løgstrup, K. E. (1938), “Teologi og Humaniora”, Dansk Teologisk Tidsskrift 1/1938, 3-13.

Modeus, Fredrik (2005), Mod att vara kyrka - om församlingsbygga och kyrkans identitet, Stockholm.

Niemelä, Kati (2007), "Alienated or disappointed? Reasons for leaving the Church in Finland", Nordic Journal of Religion and Society, 20 (2), 195216.

Prenter, Regin (1983), Den kirkelige anskuelse. En indførelse i N. F. S. Grundtvigs folkelige og kristelige grundtanker, Christiansfeld.

Prenter, Regin (1987), "Liturgy and Theology", i Prenter, Regin, Theologie und Gottesdienst: Gesammelte Aufsätze, Århus, 131-159.

Schjørring, Jens Holger (1987), Grundtvig og påsken, København.

Schjørring, Jens Holger (1990), Grundtvigs billedsprog og den kirkelige anskuelse, København.

Schjørring, Jens Holger (1999). "Trosbekendelse og kirkesyn hos Grundtvig og Bonhoeffer", Ordet og livet. Festskrift til Christian Thodberg, Aarhus.

Schjørring, Jens Holger (red.) (1988), Menneske først, kristen så. Helge Grells Grundtvig-disputats til debat, København.

Taylor, Charles (2007), A Secular Age, London.

Uggla, Bengt Kristensson, 2010, Gustaf Wingren, människan och teologin, Stockholm.

Vikström, Björn (2008), Folkkyrka i en postmodern tid. Tjänsteproducent $i$ välfärdssamhället eller engagerande gemenskap?, Åbo.

Ward, Pete (2008), Participation and Mediation. A Practical Theology for the Liquid Church, London.

Aagaard, Anna Marie (1973), Helligånden sendt til verden, Århus.

Aagaard, Anna Marie (1976), Tema og tolkninger, Århus.

Aagaard, Anna Marie (1991), Identifikation af kirken, København.

Aagaard, Anna Marie (2005), And har krop, København.

Bidraget, der er en bearbejdet udgave af en gæsteforelæsning ved Det Teologiske Fakultet, Uppsala Universitet, den 26. januar 2012 i anledning af tildelingen af æresdoktorgraden i teologi til forfatteren, er tilegnet det uppsalensiske fakultet. 